disease were arrested until the scientific statistician was fully satisfied by figures we should probably have to wait till the next century before anything was done. He must know that in medicine a strong consensus of skilled observers, a strong probability, and hypotheses that best explain the facts have all led to successful efforts for the treatment and prevention of disease. Dr. Reid can find for himself any number of recorded family histories in which alcoholism was the main element in individual and race degenera tion. I maintain that the general consensus of medical observations strongly and almost unanimously agrees with "M.D., B.S. Lond.'s" conclusions. I believe the following quotation from Dr. John Macpherson's recent admirable work on "Mental Affections" wijl be homologated by 99 out of every 100 members of our profession: "From such facts as the foregoing, and many others of a similar nature which might be cited, we perceive that the influence of alcoholic excess in the parents induces in their descendants a debilitated constitution, disorders of nutrition, a low resistive power, a tendency to contract infectious diseases; in short, a general neurosis or diathesis out of which may spring one or other of the numerous affections of the nervous system which depend upon disordered nutrition."

Dr. Reid's second question takes the form of a challenge " to indicate a single instance in which prohibitory laws have not been followed by increased drunkenness as well as by a general degradation of the public morals." Few of us adrocate "probibitory" laws, but many of us do strongly urge on the State to increase the control and regulation of the excessive sale of alcoholic drinks. On these lines I take up Dr. Reid's challenge. In 1833 Norway had no excise or licensing laws and the consumption of spirits then amounted to 16 litres per head of the population, drunkenness being lamentably prevalent and increasing. The effects of this on the public health and morals were so bad that the Norwegian Government passed a stringent law controlling and regulating the distilling and sale of spirits. The good effects of this legislation were at once apparent, and in 1899 only 3.3 litres of spirits per head of the population were consumed. In short, Norway as a nation has been made sober, not by religious or moral suasion, but by legislation controlling and regulating the sale of spirits. The moral state and health of the people have been enormously improved. If $\mathrm{Dr}$. Reid will pardon me, I would like, with much deference, to make two suggestions. Let him carefully study the facts about alcohol and alcoholic legislation to be found in Messrs. Rowntree and Sherwell's recent work. Let him also go into a low street in London, Glasgow, or Edinburgh when the public-houses are shutting on a Saturday night and thus study the price of possible alcoholic immunity that is to come 200 years bence in his fellow creatures who emerge from those houses, and let him then accompany a few of them to their homes, taking a look at their children to see the signs of degeneration, hereditary or otherwise. If modern preventive medicine had pursued a fatalistic inertia founded on letting the doctrine of the survival of the fittest take its natural course the death-rate of Great Britain would still have been about 25 per 1000 of the living. Surely the man who uses any theoretical doctrine-of alcoholic immunity or otherwiseas a spoke in the wheel of health reform or social amelioration incurs a tremendous responsibility and should be very sure of his ground.

I am, Sirs, yours faithfully,

Edinburgh, April 8tb, 1901. T. S. Olouston.

\section{THE MEDICAL PROFESSION AND THE BUDGET.}

To the Editors of THW LANOET.

SIRS, - There is no doubt that the income-tax presses most heavily upon the professional classes, and of the professions to the greatest degree upon the members of the medical profession, because their lives and healths are the more precarious and exposed to the assanlts of disease both by night and day. As it is well known that their expectation of life is the shortest of all the professions, consequently their productive period is also of the shortest. After a most costly education the medical man finds that his working expenses are greater than that of any other profession, that his bad debts are more numerous, and that the calls upon his charity are such that the profession to which be belongs probably contributes in value three-fourths of the vast medical charities of the kingdom.
The medical and surgical services gratuitously given to the sick poor and to those who consider themselves poor represent a pecuniary value of some millions of money-2 grant in aid of the sick poor, contributed to alone by the medical profession, and by so much relieves the rates, both county and parochial, because, if it were not for medical charity this medical and surgical aid would have to be provided by the public and paid for by taxation. An argument, as shallow as it is exasperating, is always trotted out by hospital committees and lay managing secretaries on this point to the effect that the experience gained by the medical staff in working for nothing more than squares the bargain. They do not see that the same argument applies to all professions. A new judge or barrister, or Prime Minister or bishop, or managing director, in the course of the practice of their calling, obtain valuable experiencethey get paid for it all the same. They are not told, as we are, that the experience and reputation attache to holding a prominent public appointment is in itself a sufficient reward and pecuniary discharge in full for value received. The public fail to see, and we are to backward in proclaiming, that experience per se gained in giving gratuitous medical service has no value that it would not equally possess if those services were adequately remunerated. It is necessary to emphasise this point in view of the many hospital management controversies now raging. It can be shown, therefore, that the relation of the medical profession to the public is in this way different to that of any other profession or calling and consequently we can claim special treatment and leniency in the matter of taxation. Instead of leniency as a body, we are exploited and practically scalped, and skinned by successive Chancellors of the Exchequer. At one of the recent Budgets one of the Chancellors actually chuckled with delight at the amount of income-tax that had been squeezed out of the medical profession and our profession was so feebly represented in the House that there was no one sufficiently instructed or articulate to explain that the exigencies of their calling prevented medical men from appealing against excessive assessment or agitating against the unequal incidence of direct and indirect taxation which pressed so heavily upon their burdened shoulders.

To condescend to particulars I would suggest: (1) that the medical man's house should be rated and assessed as a house of business ; and (2) that the payments to sick and benevo lent societies should rank with life assurance premiums and be deducted from income for taxation purposes.

Provision in case of sickness or poverty is as worthy of national encouragement as providing for early deathindeed, they are often linked together in one sad chain of misfortune. To obtain these slight concessions the pro. fession must organise and become loudly vocal, and we look to the medical press to aid us powerfully to become so. I am, Sirs, yours faithfully, A. H. BAMPTON, M.D.R.U.I.

Ilkley-in-Wharfedale, April 10th, 1901.

\section{"THE TEACHING OF AN ÆSTHETICS."}

\section{To the Editors of THE LANCET.}

SIRS,-In The LANCET of April 6th, p. 1041, LieutenantColonel Edward Lawrie, I.M.S., complains that he has been attacked "for hampering the important q'estion of making the teaching of anæsthetics a recognised part of the medical curriculum by introducing side issues." It cannot fail to impress the reader of his remarks that his letter emphasises the justice of the strictures which have been passed upon him when be proceeds to give an entirely imaginary description of the clinical teaching of anæsthetics in the London hospitals. As long as 11 years ago my own fellow-students were most thoroughly taught and clinically trained by Dr. F. Hewitt at Charing Cross Hospital. After a series of lectures we administered a number of anæsthetics ourselves under his supervision, were encouraged to attend as many cases as possible, and were only granted a certificate of proficiency when he was satisfied that it had been deserved.

Dr. Hewitt's teaching began long before this, and has continued on the same lines to the present day. The anæsthetists at all the London hospitals with teaching schools now follow the plan of making the students themselves administer the ether and chloroform to as many patients as is practicable, so that Lieutenant-Colonel 